\title{
Detection of oestrogenic activity of steroids present during mammalian gestation using oestrogen receptor $\alpha$ - and oestrogen receptor $\beta$-specific in vitro assays
}

\author{
J G Lemmen, C E van den Brink, J Legler, P T van der Saag \\ and $\mathbf{B}$ van der Burg
}

Hubrecht Laboratory, Netherlands Institute for Developmental Biology, Uppsalalaan 8, 3584 CT Utrecht, The Netherlands

(Requests for offprints should be addressed to B van der Burg; Email: bvdb@niob.knaw.nl)

\begin{abstract}
Numerous steroid hormones are present in the foetus but their potential to activate oestrogen receptor (ER) $\alpha$ and/or $\beta$ is largely unknown. In this study, in vitro assays were developed to rapidly and specifically detect ER $\alpha$ or ER $\beta$ activation by these steroid hormones. Our results showed that several oestrogen precursors and androgens are able to activate both $\operatorname{ER} \alpha$ and $\operatorname{ER} \beta$. Of special interest is that some of these precursors are able to activate ER $\alpha$ and $\operatorname{ER} \beta$ at concentrations that are present during human gestation. Moreover, some precursors (dehydroepiandrosterone (DHEA) and 17-hydroxylated pregnenolone sulphate) and androgens (5-androsten-3 $\beta, 16 \alpha, 17 \beta$-triol and testosterone) showed a more than 100 -fold relative preference for $\mathrm{ER} \beta$ transactivation over $\mathrm{ER} \alpha$ transactivation
\end{abstract}

when compared with $17 \beta$-oestradiol. Due to their relatively high levels, the precursor steroids DHEA and pregnenolone may be of particular importance in the regulation of ER $\beta$ activity in vivo. To obtain information about the oestrogenic activity of the total pool of steroid hormones present during mammalian gestation, steroids were extracted from mouse embryos at different prenatal stages and assayed for oestrogenic activity in the established in vitro assays. Oestrogenic activity was detected in steroid extracts from all stages tested. This study has demonstrated that oestrogen receptor agonists are present in the murine embryo and that oestrogen precursors may contribute to the total pool of agonists during foetal life.

Journal of Endocrinology (2002) 174, 435-446

\section{Introduction}

Oestrogens are steroid hormones with numerous target tissues in both males and females, tissues such as the reproductive tract, gonad, mammary gland, bone tissue, cardiovascular system and the central nervous system. Endogenous oestrogens are synthesised from cholesterol via the conversion of various precursors (Fig. 1A). Cholesterol from the diet is converted by p450-sidechain-cleavage enzyme (CYP11A1) to pregnenolone, which then is converted to either 17-hydroxy (OH)pregnenolone or progesterone. The conversion to $17 \mathrm{OH}-$ pregnenolone is mediated by $17 \alpha$-hydroxylase (CYP17), while $3 \beta$-hydroxysteroid dehydrogenase $(3 \beta-H S D)$ and $\Delta^{5,4}$-ketosteroid isomerase mediate the formation of progesterone. Progesterone can be further hydrolysed to $17 \mathrm{OH}$-progesterone by 17,20 lyase (CYP17). Subsequently, both $17 \mathrm{OH}$-pregnenolone and $17 \mathrm{OH}-$ progesterone can serve as a substrate for CYP17 to form dehydroepiandrosterone (DHEA), which is oxidised to androstenedione by $3 \beta-H S D$. Finally, androstenedione is aromatised to oestrone by aromatase (CYP19) or hydro- lysed by $17 \beta$-hydroxysteroid dehydrogenase (17 $\beta$-HSD) to testosterone. Testosterone can be aromatised to $17 \beta-$ oestradiol or converted to dihydrotestosterone by $5 \alpha-$ reductase. This last conversion occurs mainly in males.

During human gestation, the maternal-placental-foetal unit (MPF unit) is the main source of steroid hormones after 8 weeks of gestation (Solomon 1994). However, the human placenta lacks the CYP17 enzyme (Voutilainen \& Miller 1986) and placental steroids downstream of the CYP17 conversion steps are therefore derived from either maternal or foetal precursors (Fig. 1B). The foetal-derived precursors for oestrogen formation in the placenta are DHEA-sulphate (DHEAS) and 16OH-DHEAS formed in the foetal liver and adrenal respectively. In the sulphataserich placenta (Pasqualini \& Kincl 1985), DHEAS and $16 \mathrm{OH}-\mathrm{DHEAS}$ are desulphated to DHEA and $16 \mathrm{OH}-$ DHEA, which are the substrates for $3 \beta-H S D$ to form androstenedione and androstenetriol. Androstenedione serves as a precursor for both oestrone and $17 \beta$-oestradiol, while androstenetriol is a precursor for oestriol. In addition, $16 \mathrm{OH}$-androstenedione formed from $16 \mathrm{OH}-$ DHEAS can be metabolised to oestriol (Numazawa et al. 
A

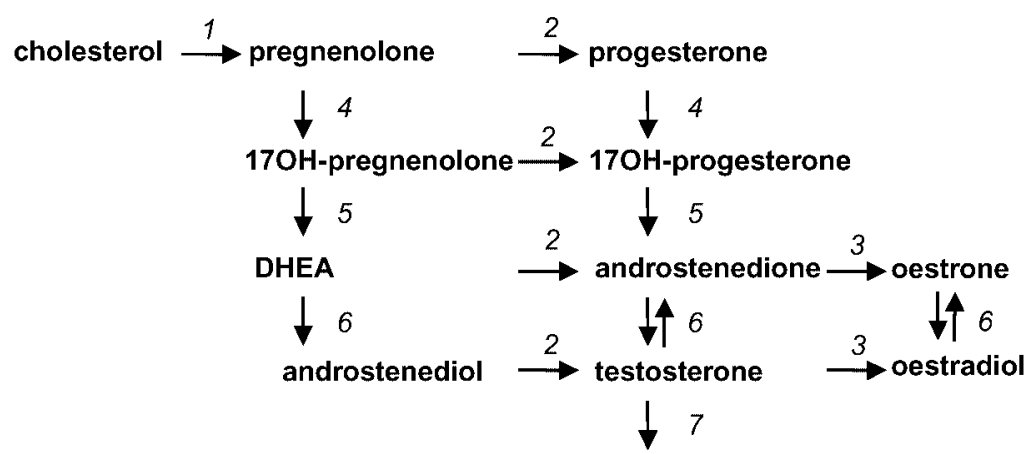

dihydro-testosterone

\section{B}

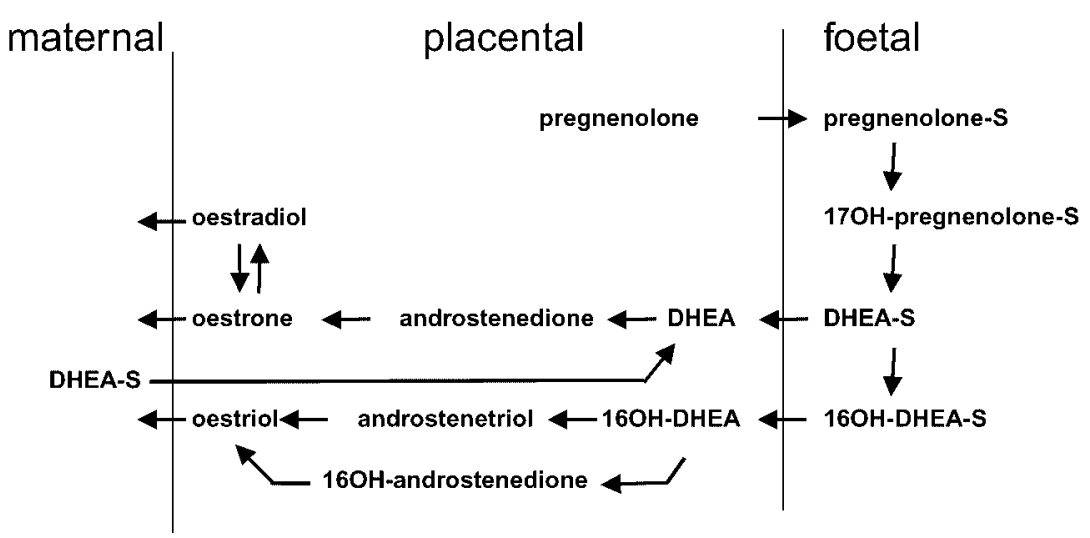

Figure 1 Biosynthesis pathway of steroids in the human and presence of steroids in the human maternal-placental-foetal (MPF) unit. (A) Biosynthesis pathway of steroids. Numbers refer to enzymes: (1) p450-side-chain-cleavage enzyme, (2) 3ß-hydroxysteroid dehydrogenase, (3) aromatase, (4) 17,20 lyase, (5) 17 $\alpha$-hydroxylase, (6) 17 $\beta$-hydroxysteroid dehydrogenase, (7) 5 $\alpha$-reductase. (Adapted from Gore-Langton \& Armstrong 1994 and Ojeda 1996.) (B) Steroids in the human maternal-placental-foetal unit. (Adapted from Solomon 1994 and Carr 1996.)

1985). Most of the steroids present in the foetus are sulphated, which is believed to reduce their biological activity (Pasqualini \& Kincl 1985).

Mice differ to some degree from humans with regard to steroid hormone synthesis during gestation. The main oestrogen produced during murine gestation is $17 \beta-$ oestradiol versus oestriol in humans (Pasqualini \& Kincl 1985). While foetal concentrations of steroid precursors have been well studied in humans (Guez et al. 1976, Den et al. 1979, Mathur et al. 1980, de Peretti \& Mappus 1983), little is known of their levels in mice. Differences between mice and humans in the activity of the enzymes involved in steroidogenesis have been found; this could lead to a difference in the relative amounts of precursors present in the two species. Furthermore, binding proteins in serum, which may influence the concentration of hormone that is biologically available, differ in the two species. In mice, the main oestrogen-binding protein during gestation is $\alpha$-foetoprotein, whereas in humans $\alpha$-foetoprotein has been shown not to bind oestrogens. In humans, one of the major oestrogen-binding proteins is sex steroid-binding protein which, like $\alpha$-foetoprotein, is upregulated by oestrogens (reviewed by Pasqualini \& Kincl 1985).

The effects of oestrogens are mediated through oestrogen receptors, which are ligand-dependent transcription factors. In mammals, two oestrogen receptors are known to exist, oestrogen receptor (ER) a (Green et al. 1986) (NR3A1 according to the Nuclear receptors nomenclature committee (1999)) and ER $\beta$ (Kuiper et al. 1996, Mosselman et al. 1996) (NR3A2). Both ER $\alpha$ and ER $\beta$ are expressed during embryogenesis in many species including 
humans (Takeyama et al. 2001) and mice (Lemmen et al. 1999). However, the function of oestrogens and their receptors during normal development of the foetus remains unclear. When either ER $\alpha$ (Lubahn et al. 1993) or ER $\beta$ (Krege et al. 1998) or both receptors (Couse et al. 1999, Dupont et al. 2000) are knocked out, no gross prenatal phenotypes have been observed in mice, suggesting that oestrogen receptors are not essential for prenatal development. On the other hand, prenatal exposure of animals or humans to the synthetic oestrogen diethylstilboestrol (DES) have been reported to induce abnormalities in various organs (Herbst et al. 1971, McLachlan et al. 1975). This indicates that prenatally expressed oestrogen receptors are functional with respect to transducing the effects of this synthetic oestrogen. In humans, an increased risk for developing breast and prostate cancer as well as cryptorchidism and low sperm counts has been hypothesised to be linked with exposure to exogenous oestrogens during gestation (Sharpe \& Skakkebaek 1993, Miller \& Sharpe 1998, Toppari \& Skakkebaek 1998). The possible contribution of endogenous steroid hormones to the development of such abnormalities remains unclear (Shibata \& Minn 2000).

The present study was carried out in order to elucidate the oestrogenic potential of steroid hormones present in the human MPF unit. For this purpose, novel cell lines stably transfected with the human ER $\alpha$ and $\operatorname{ER} \beta$ together with an oestrogen-responsive reporter construct were made. Steroid hormones and their precursors known to be present in the human MPF unit were tested in the developed cell lines in order to separately determine their ability to activate ER $\alpha$ or ER $\beta$. In order to assess the combined oestrogenic activity of the total steroid pool, steroids extracted from mouse embryos were tested in the cell lines. Our results show that several steroids, usually not considered to be oestrogenic, were able to activate ERs, some at physiological levels present in the human foetus. In addition, oestrogenic activity could be detected in steroid extracts from embryonic mice, using the same assay system. These findings confirm the presence of biologically active oestrogens in mammalian embryos.

\section{Materials and Methods}

\section{Reagents}

Androstenedione (4-androstene-3,17-dione, 98\%), 16OHandrostenedione (4-androsten-16 $\alpha$-ol-3,17-dione), $3 \beta$-androstanediol ( $5 \beta$-androstane-3 $\beta, 17 \beta$ diol), cholesterol (5-cholesten-3 $\beta$-ol), DHEA-3-sulphate (5-androsten-3 $\beta$-ol-17one sulphate, 98\%), dexamethasone ( $9 \alpha$-fluoro-16 $\alpha$-methyl-11 $\beta, 17 \alpha, 21$-trihydroxy-1,4-pregnadiene-3,20-dione), DES $(99 \%), 5 \alpha$-dihydrotestosterone $(5 \alpha$-androstan- $17 \beta$ ol-3-one), $\quad 17 \beta$-oestradiol $(1,3,5[10]$-estatriene-3,17 $\beta$ diol, 99\%), oestriol (1,3,5[10]-estatriene-3,16 $\alpha, 17 \beta$-triol, $99 \%)$, oestrone $(1,3,5[10]$-estatrien-3-ol-17-one, $99 \%)$, pregnenolone (5-pregnen-3 $\beta$-ol-20-one, 98\%), progesterone (4-pregnene-3,20-dione), testosterone (4-androsten-17 $\beta$-ol-3-one), tamoxifen (1-p- $\beta$-dimethylaminoethoxy-phenyl-trans-1,2-diphenyl but-1-ene, 99\%) and all-trans retinoic acid were obtained from Sigma-Aldrich (Zwijndrecht, The Netherlands). DHEA (5-androsten3ß-ol-17-one, 99\%) was from Fluka Chemie (SigmaAldrich). Pregnenolone sulphate (pregnenolone-S; 5-pregnen-3 $\beta$-ol-20-one-sulphate), $17 \mathrm{OH}$-pregnenolone (5-pregnen-3 $\beta, 17$-diol-20-one), $17 \mathrm{OH}$-pregnenolone-S (5-pregnen-3 $\beta, 17$-diol-20-one-sulphate), 5-androsten-3 $\beta$, $16 \alpha, 17 \beta$-triol and $16 \mathrm{OH}$-DHEAS (5-androsten-3 $\beta, 16 \alpha-$ diol-17-one-sulphate) were obtained from Steraloids Inc. (Newport, RI, USA). ICI 182780 was a gift from Dr A Wakeling, Zeneca Pharmaceuticals (Cheshire, UK). 2,3,7,8-Tetrachlorodibenzo-p-dioxin was kindly provided by $\operatorname{Dr} M$ van den Berg (RITOX, Utrecht, The Netherlands). The synthetic androgen receptor agonist R1881 was a gift from Dr A Brinkman (Erasmus University Rotterdam, The Netherlands). The synthetic progestin Org 2058 was a gift from Dr H J Kloosterboer (NV Organon, Oss, The Netherlands). For the exposure of the cells, all chemicals were diluted in either ethanol (100\%; Sigma-Aldrich) or dimethylsulphoxide (DMSO; 99.9\%; Acros, Geel, Belgium). The antibiotic hygromycin B was from Roche Molecular Biochemicals (Mannheim, Germany) and neomycin (G 418) was obtained from Life Technologies (Breda, The Netherlands). $\beta$ Glucuronidase/sulphatase from Helix pomatia was obtained from Sigma-Aldrich.

\section{DNA constructs}

The oestrogen-responsive reporter gene construct $(3 \times$ ERE-TATA-Luc) which contains three copies of a consensus oestrogen-response element (ERE) containing oligonucleotide and a TATA box in front of the luciferase cDNA is described in more detail elsewhere (Legler et al. 1999). This synthetic construct was chosen since it contained only EREs and reporter transactivation would then be solely via these EREs. If the promoter of a certain oestrogen target gene had been chosen responsive elements other than EREs would have been present and reporter activation could have occurred without oestrogen receptor activation. In stable transfectants, the human ER $\alpha$ expression plasmid pSG5-HEGO (kindly provided by Dr P Chambon, IGBMC, Strasbourg, France) was used. The human ER $\beta$ full-length plasmid, pSG5-hER $\beta$ (530 amino acids), was provided by Dr J-A Gustafsson (Karolinska Institute, Huddinge, Sweden).

\section{Stable cell lines}

Human embryonic kidney 293 (293 HEK) cells were obtained from the American Type Culture Collection 
(ATCC; Manassas, VA, USA). A stable cell line was made with $3 \times$ ERE-TATA-Luc cotransfected with a hygromycin B resistance gene (te Riele et al. 1990). Subsequently $\mathrm{ER} \alpha$ or $\operatorname{ER} \beta$ were transfected in this cell line together with a neomycin resistance gene (Sonneveld et al. 1998) using the calcium phosphate precipitation method (Banerji et al. 1981). Several clones from $\operatorname{ER} \alpha$ and $\operatorname{ER} \beta$ cell lines were tested for their response to $17 \beta$-oestradiol. One clone for 293ER $\alpha$-ERELuc (clone 35) and one clone for 293ER $\beta$-ERELuc (clone 52) were selected for their consequent high response to $17 \beta$-oestradiol and are described further in this paper.

The 293 HEK stable cell lines were cultured in a 1:1 mixture of Dulbecco's modified Eagle's medium and Ham's F12 medium (DF; Gibco, Life Technologies, Breda, The Netherlands) supplemented with $7 \cdot 5 \%$ foetal calf serum (Integro, Linz, Austria), 50 $\mathrm{g} / \mathrm{ml}$ hygromycin B and $200 \mu \mathrm{g} / \mathrm{ml} \mathrm{G418.} \mathrm{The} \mathrm{cells} \mathrm{were} \mathrm{rinsed} \mathrm{twice} \mathrm{with}$ phosphate-buffered saline (PBS) without calcium and magnesium, trypsinised and suspended in phenol red-free DF medium containing $3 \times 10^{-8} \mathrm{M}$ selenite, $10 \mu \mathrm{g} / \mathrm{ml}$ transferrin and $0 \cdot 2 \%$ bovine serum albumin (BSA), supplemented with 5\% dextran-coated charcoal-stripped foetal calf serum (DCC-FCS). They were plated in 96-well tissue culture plates (NUNC, Life Technologies, Breda, The Netherlands) (45000 cells per $\mathrm{cm}^{2}$ ) at a volume of $200 \mu \mathrm{l}$ per well. Forty-eight hours later the medium was refreshed and the compounds to be tested (dissolved in ethanol or DMSO) were added directly to the medium at a 1:1000 dilution. After an additional $24 \mathrm{~h}$, the medium was removed and $50 \mu$ lysis solution was added directly to the wells $(1 \%(\mathrm{v} / \mathrm{v})$ Triton $\mathrm{X}-100$, $2.5 \times 10^{-2} \mathrm{M}$ glycylglycine, $1.5 \times 10^{-2} \mathrm{M} \mathrm{MgSO}_{4}$, $4 \times 10^{-3} \mathrm{M}$ EGTA and $1 \times 10^{-3} \mathrm{M}$ dithiothreitol). The luciferase activity of $25 \mu \mathrm{l}$ of the cell lysates was measured with the luclite luciferase reporter gene assay kit (Recorder no. 6016911; Packard Instruments, Groningen, The Netherlands) according to the manufacturer's instructions using $25 \mu \mathrm{l}$ luclite solution, using a Topcount liquid scintillation counter (Packard Instruments).

\section{$R T-P C R$}

RT-PCR was carried out as described previously (Quaedackers et al. 2001). Briefly, clones of the 293 HEK stable cell lines were cultured in $100 \mathrm{~mm}$ dishes and total RNA was isolated using the acid-phenol method (Chomczynski \& Sacchi 1987). COS-1 cells (ATCC), transiently transfected with human (h) $\operatorname{ER} \alpha$ and hER $\beta$, were used as positive controls. cDNA was made with Superscript reverse transcriptase from $1 \mu \mathrm{g}$ DNAse-treated total RNA according to the manufacturer's instructions. Aliquots of $5 \mu \mathrm{l}$ cDNA and $1 \mu \mathrm{g}$ DNAse-treated total RNA were used in a PCR for hER $\alpha, \operatorname{hER} \beta$ and $\beta$-actin. For PCR of hER $\alpha$, forward primer $5^{\prime}$-GACAAGGGAA
GTATGGCTATGGA-3' and 5'-TTCATCATTCCC ACTTCGTAGC-3' reverse primer were used. For PCR of hER $\beta$, forward primer $5^{\prime}$-TAGTGGTCCATCGCC AGTTAT $-3^{\prime}$ and reverse primer $5^{\prime}$-GGGAGCCACACT TCACCAT- $3^{\prime}$ were used. Twenty-five PCR cycles were used $\left(1 \min 96^{\circ} \mathrm{C}, 1 \min 55^{\circ} \mathrm{C}\right.$ and $\left.1 \min 72^{\circ} \mathrm{C}\right)$. All cDNA samples used tested positive in the $\beta$-actin PCR (results not shown). The DNAse-treated total RNA samples were negative in all three PCR reactions (results not shown).

\section{Determination of receptor number}

The receptor number was determined by Scatchard analysis as described previously (Quaedackers et al. 2001). Briefly, cells were plated out in 6-well plates (45 000 cells per $\mathrm{cm}^{2}$ ) in DF medium with 5\% DCC-FCS. Two days later, at approximately $80 \%$ confluency, cells were rinsed with PBS and incubated for $1 \mathrm{~h}$ in phenol red-free DF medium containing $3 \times 10^{-8} \mathrm{M}$ selenite, $10 \mu \mathrm{g} / \mathrm{ml}$ transferrin and $0.2 \%$ BSA with increasing amounts of tritiated 17 $\beta$-oestradiol (Amersham, Roosendaal, The Netherlands) with and without 200-fold excess of unlabelled $17 \beta$-oestradiol. A sample of the medium was counted in a liquid scintillation counter to determine the exact exposure concentration of tritiated $17 \beta$-oestradiol. Medium was discarded and the cells were rinsed with PBS and incubated for $1 \mathrm{~h}$ in $0.5 \mathrm{M} \mathrm{NaOH}$ to lyse the cells. A sample of the cell lysates was counted in a liquid scintillation counter and another sample of the lysate was used for estimation of the protein content using the BioRad protein assay according to the manufacturer's instructions (BioRad, München, Germany). The dissociation constant $\left(K_{\mathrm{d}}\right)$ and the number of receptor sites $\left(\mathrm{B}_{\max }\right)$ were calculated by performing a Scatchard analysis, by plotting bound/free $17 \beta$-oestradiol as a function of bound $17 \beta$ oestradiol. The $K_{\mathrm{d}}$ is the concentration of $17 \beta$-oestradiol where $50 \%$ of the receptor sites are occupied and was calculated from the slope of the curve $\left(K_{\mathrm{d}}=-1 /\right.$ slope $)$; the $\mathrm{B}_{\max }$ is given by the $\mathrm{x}$ intercept.

\section{Steroid extractions and desulphation}

Steroids were extracted from mouse embryos aged 12-16 days post coitum (dpc). Ovary and liver from adult females, as well as embryos treated in utero $(24 \mathrm{~h})$ with $1 \mathrm{mg}$ DES per mother, were used as positive controls. The method used for steroid extraction was adapted from Maume et al. (2001). Briefly, individual embryos (100$800 \mathrm{mg}$ ) were homogenised by sonification in 300$1500 \mu \mathrm{l}$ methanol and extracted twice with an equal amount of chloroform. The organic chloroform fraction was extracted twice with an equal volume of hexane to remove lipids. Acetate buffer $(1 \mathrm{ml})$ was added and 
Table 1 Relative transactivation activity of various hormones towards $E R \alpha$ and $E R \beta$ in 293 cell lines

\begin{tabular}{|c|c|c|c|c|c|c|}
\hline & $\mathrm{ER \alpha}$ & & ERß & & & \\
\hline & $\mathrm{EC} 25^{\mathrm{a}}$ & $\begin{array}{l}\text { Relative } \\
\text { potency } \\
\text { to } \mathrm{E} 2^{\mathrm{b}}\end{array}$ & EC25 & $\begin{array}{l}\text { Relative } \\
\text { potency } \\
\text { to E2 }\end{array}$ & 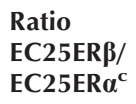 & $\begin{array}{l}\text { preference } \\
\text { for } E R \beta \text { in } \\
\text { respect to } E 2 \alpha^{d}\end{array}$ \\
\hline Ligand & & & & & & \\
\hline 5 -Androsten-3 $\beta, 16,17 \beta$-triol & $4.2 \times 10^{-9} \mathrm{M}$ & $8 \times 10^{-5}$ & $1.6 \times 10^{-9} \mathrm{M}$ & $2 \times 10^{-2}$ & $0 \cdot 4$ & 288 \\
\hline $5 \beta$-Androstenediol & $5.6 \times 10^{-9} \mathrm{M}$ & $6 \times 10^{-5}$ & $2 \cdot 3 \times 10^{-8} \mathrm{M}$ & $2 \times 10^{-3}$ & $4 \cdot 1$ & 28 \\
\hline Androstenedione* & $\mathrm{nr}$ & - & $3 \cdot 3 \times 10^{-6} \mathrm{M}$ & $1 \times 10^{-5}$ & - & - \\
\hline $16 \mathrm{OH}$-androstenedione & $\mathrm{nr}$ & - & $\mathrm{nr}$ & - & - & - \\
\hline Cholesterol & $\mathrm{nr}$ & - & $\mathrm{nr}$ & - & - & - \\
\hline DHEA & $2.6 \times 10^{-8} \mathrm{M}$ & $1 \times 10^{-5}$ & $1 \cdot 3 \times 10^{-8} \mathrm{M}$ & $3 \times 10^{-3}$ & $0 \cdot 5$ & 230 \\
\hline DHEAS & $1.5 \times 10^{-6} \mathrm{M}$ & $2 \times 10^{-7}$ & $3.9 \times 10^{-6} \mathrm{M}$ & $1 \times 10^{-5}$ & $2 \cdot 6$ & 44 \\
\hline 16OH-DHEA & $2 \cdot 0 \times 10^{-8} \mathrm{M}$ & $2 \times 10^{-5}$ & $3.9 \times 10^{-8} \mathrm{M}$ & $1 \times 10^{-3}$ & $2 \cdot 0$ & 58 \\
\hline Oestradiol & $3.4 \times 10^{-13} \mathrm{M}$ & 1 & $3.9 \times 10^{-11} \mathrm{M}$ & 1 & 115 & 1 \\
\hline Oestriol & $3.7 \times 10^{-12} \mathrm{M}$ & $9 \times 10^{-2}$ & $2 \cdot 1 \times 10^{-11} \mathrm{M}$ & 2 & $5 \cdot 7$ & 20 \\
\hline Oestrone & $7 \cdot 1 \times 10^{-12} \mathrm{M}$ & $5 \times 10^{-2}$ & $7.6 \times 10^{-11} \mathrm{M}$ & $5 \times 10^{-1}$ & $10 \cdot 7$ & 11 \\
\hline Pregnenolone & $2.9 \times 10^{-5} \mathrm{M}$ & $1 \cdot 2 \times 10^{-8}$ & $5.4 \times 10^{-5} \mathrm{M}$ & $7 \times 10^{-7}$ & 1.9 & 61 \\
\hline Pregnenolone-S* & $7 \cdot 8 \times 10^{-5} \mathrm{M}$ & $4.4 \times 10^{-9}$ & $8.4 \times 10^{-5} \mathrm{M}$ & $4 \times 10^{-7}$ & $1 \cdot 1$ & 105 \\
\hline $17 \mathrm{OH}$-pregnenolone* & $1.5 \times 10^{-6} \mathrm{M}$ & $2 \times 10^{-7}$ & $3.0 \times 10^{-6} \mathrm{M}$ & $1 \times 10^{-5}$ & 2 & 58 \\
\hline $17 \mathrm{OH}$-pregnenolone-S* & $2 \cdot 0 \times 10^{-6} \mathrm{M}$ & $1 \times 10^{-7}$ & $1.2 \times 10^{-6} \mathrm{M}$ & $3 \times 10^{-5}$ & 0.6 & 192 \\
\hline Progesterone & $\mathrm{nr}$ & - & $\mathrm{nr}$ & - & - & - \\
\hline Testosterone & $8 \cdot 1 \times 10^{-5} \mathrm{M}$ & $4 \times 10^{-9}$ & $6.0 \times 10^{-5} \mathrm{M}$ & $6 \times 10^{-7}$ & $0 \cdot 7$ & 164 \\
\hline Dihydrotestosterone & $3.6 \times 10^{-8} \mathrm{M}$ & $9 \times 10^{-6}$ & $1.0 \times 10^{-7} \mathrm{M}$ & $4 \times 10^{-4}$ & $2 \cdot 8$ & 41 \\
\hline
\end{tabular}

aThe EC25 values were calculated by determining the concentration by which $25 \%$ of maximum activity was reached using the sigmoidal fit equation. For test compounds not reaching plateau levels (indicated with *) necessary to calculate the EC25, and EC25 was calculated using the concentration of the test compound eliciting the same level of luciferase induction as the EC25 for $17 \beta$-oestradiol (E2).

${ }^{\mathrm{b}}$ The potency relative to $\mathrm{E} 2$ is the EC25 of $17 \beta$-oestradiol divided by the EC25 of the tested hormone.

The ratio of the EC25 of the hormone for ER $\beta$ divided by the EC25 of the hormone for ER $\alpha$, a number smaller than 1 represents a relative preference for transactivating ER $\beta$.

${ }^{\mathrm{d}}$ The relative preference for ER $\beta$ in comparison with $17 \beta$-oestradiol. The EC25ER $\beta / \mathrm{EC} 25 \mathrm{ER} \alpha$ ratio for $17 \beta$-oestradiol divided by the EC25ER $\beta /$ EC25ER $\alpha$ ratio of the hormone.

nr, not reached.

extracted twice with an equal volume of ethyl acetate. The ethyl acetate fraction containing free steroids was evaporated under an $\mathrm{N}_{2}$ gas flow and the extract was then transferred to a conical glass vial. The test tube was rinsed with ethyl acetate, which was transferred to the vial and subsequently evaporated under an $\mathrm{N}_{2}$ gas flow. The extract was dissolved in $10 \mu \mathrm{l}$ DMSO. The water fractions remaining after ethyl acetate extraction were stored at $-20{ }^{\circ} \mathrm{C}$ until further analysis. Steroid conjugates in the remaining water phases were deglucuronidated and desulphated overnight using $\beta$-glucoronidase/sulphatase from Helix pomatia $\left(400 \mathrm{U} / \mathrm{ml}\right.$ ) at $37^{\circ} \mathrm{C}$ (Legler et al. 2002). $17 \beta$-Oestradiol glucuronide $\left(1 \times 10^{-6} \mathrm{M}\right)$ served as a positive control. The deconjugated water fractions were extracted three times with ethyl acetate, evaporated as above and dissolved in $10 \mu \mathrm{l}$ DMSO. The animals used for the extraction were isolated with the approval of the Royal Netherlands Academy of Arts and Sciences Animal Ethics Committee (protocol HL01.04 and HL01.09).

\section{Data analysis}

The $17 \beta$-oestradiol curve was fitted using the sigmoidal fit $\left(y=a_{o}+a_{1} / 1+\exp \left(-\left(x-a_{2}\right) / a_{3}\right)\right)$ in Slidewrite Plus for
Windows version $3 \cdot 0$, which determines the fitting coefficients by an iterative process minimizing the $\mathrm{c} 2$ merit function (least squares criterion). The minimal detection limit was calculated as the concentration of $17 \beta$-oestradiol elicited by the solvent control plus three times the standard deviation. The EC25 and EC50 values were calculated by determining the concentration by which 25 or $50 \%$ of maximum activity was reached using the sigmoidal fit equation. For test compounds not reaching plateau levels necessary to calculate the EC25, an EC25 was calculated using the concentration of the test compound eliciting the same level of luciferase induction as the EC25 for $17 \beta$ oestradiol. The compounds concerned are indicated with an asterisk in Table 1. The oestradiol equivalents (EEQ) for the steroid extracts were calculated by interpolating the response of the (diluted) extracts in the fitted curve for $17 \beta$-oestradiol determined in the same experiment. Extracts were diluted so that their response fell within the linear portion of the $17 \beta$-oestradiol curve. Averages of the EEQ values of the steroid extracts from different sexes and ages were compared with the two-paired Student's $t$-test. Data shown are the average of at least three independent experiments with each experimental point performed in triplicate. 


\section{Results}

\section{Development of stable cell lines}

In order to evaluate oestrogenic activity of the hormones from the MPF unit, stable cell lines expressing an oestrogen-responsive reporter construct and either hER $\alpha$ or hER $\beta$ were developed. For this purpose, $293 \mathrm{HEK}$ cells were chosen because they do not express endogenous oestrogen receptors and have been shown to lack $3 \beta-H S D$ and $17 \beta-$ HSD activity (Suzuki et al. 2000). Metabolism of the tested hormones by $3 \beta$ - and $17 \beta-H S D$ is therefore negligible. In addition, previous results with transient transfection of these receptor/reporter gene constructs showed high luciferase induction of the reporter construct in these cells (Kuiper et al. 1998).

For the development of the stable cell lines, 64 antibiotic-resistant clones were isolated for $\operatorname{ER} \alpha$ and 288 for $\operatorname{ER} \beta$. For $\operatorname{ER} \alpha, 18$ clones with luciferase induction exceeding ten times the solvent control following stimulation with $1 \times 10^{-9} \mathrm{M} 17 \beta$-oestradiol were selected. For $\mathrm{ER} \beta, 58$ clones were selected in the same manner. This procedure was repeated on the selected clones. For each receptor, the three highest responding clones ( $>100$-fold for $\operatorname{ER} \alpha$ and $>50$-fold for $E R \beta$ ) were examined in more detail with full $17 \beta$-oestradiol dose-response curves (data not shown). From these three clones, the cell line with the highest fold induction was chosen for further use in this study (clone 35 for $\operatorname{ER} \alpha(293 \mathrm{ER} \alpha)$ and clone 52 for $\operatorname{ER} \beta$ (293ER $\beta)$ ).

In the 96-well-based assay the maximum fold induction by $1 \times 10^{-8} \mathrm{M} 17 \beta$-oestradiol for the $293 \mathrm{ER} \alpha$ cell line was 41 (coefficient of variation $(\mathrm{CV})=14 \%$ ) and the fold induction of the $293 \mathrm{ER} \beta$ cell line was $342(\mathrm{CV}=11 \%)$ in six independent experiments. The eight times higher fold induction in the 293ER $\beta$ cell line compared with the 293ER $\alpha$ cell line was due to a lower background level of luciferase activity in that cell line. In both cell lines, the response remained stable for more than 20 passages (data not shown).

Stable cell lines with specific oestrogen receptor expression and high sensitivity and selectivity to oestrogens

Expression of oestrogen receptors in the two cell lines was confirmed with RT-PCR (Fig. 2). In the 293ER $\alpha$ cell line, only ER $\alpha$ mRNA and no ER $\beta$ mRNA could be detected while, in the 293ER $\beta$ cell line, only ER $\beta$ mRNA was detected. The amount of receptor per mg protein determined with Scatchard analysis was $206 \mathrm{fM}$ and $161 \mathrm{fM}$ for $293 \mathrm{ER} \alpha$ and $293 \mathrm{ER} \beta$ respectively. The sensitivity of the reporter cell lines to the natural ligand $17 \beta$-oestradiol was tested and is shown in Fig. 3. The 293ER $\alpha$ cell line had an EC50 of $1.3 \times 10^{-12} \mathrm{M}$ and a minimal detectable concentration of $1 \times 10^{-13} \mathrm{M} 17 \beta$ oestradiol. The 293ER $\beta$ cell line expression had an EC50
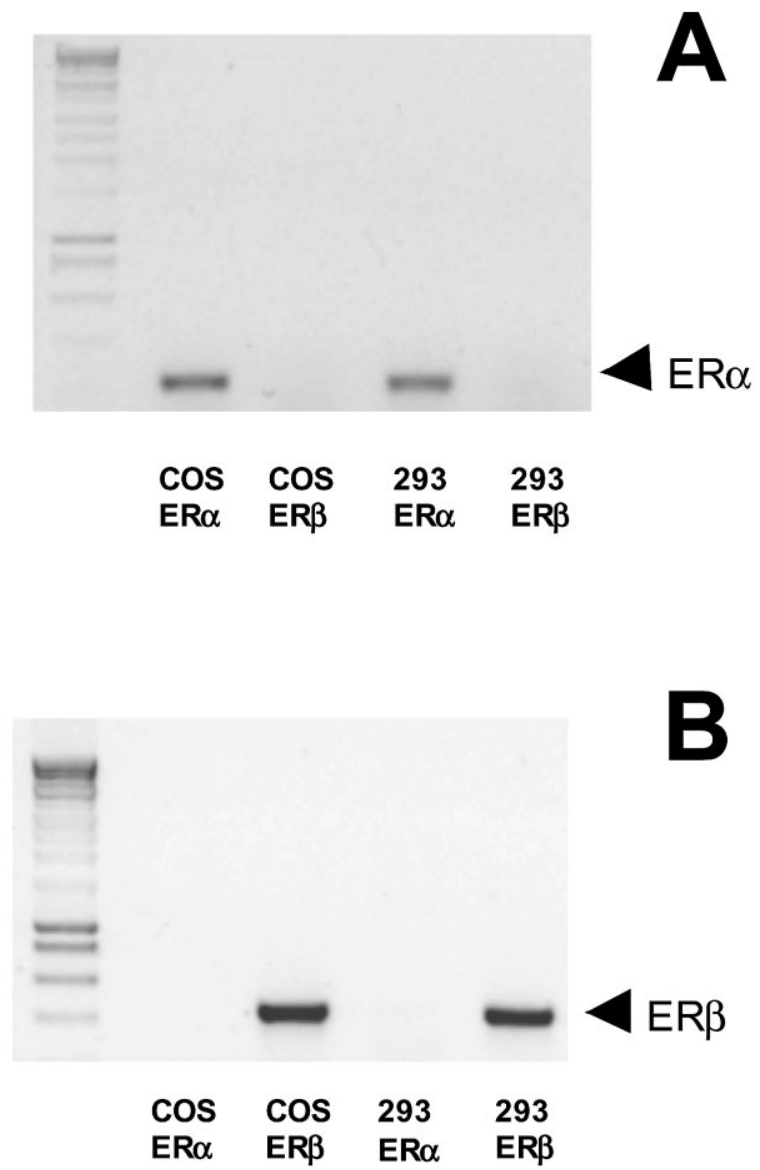

Figure 2 Expression of oestrogen receptor (ER) $\alpha$ and ER $\beta$ mRNA in stable transfectants; amplified human (h)ER $\alpha$ and hER $\beta$ cDNA. (A) hER $\alpha$ is present in the 293ER $\alpha$ cell line and not in the 293ER $\beta$ cell line. (B) hER $\beta$ is present in the 293ER $\beta$ cell line and not in the $293 E R \alpha$ cell line. As controls, COS cells were transfected with $\mathrm{hER} \alpha$ or hER $\beta$. Water and RNA samples amplified in the same PCR run were negative (data not shown).

value of $1.0 \times 10^{-11} \mathrm{M}$ and a minimal detectable concentration of $6 \times 10^{-13} \mathrm{M} 17 \beta$-oestradiol. Next, the response of the stable cell lines to different natural hormones or synthetic ligands for specific hormone receptors was tested with and without $17 \beta$-oestradiol. These compounds were chosen because interference between the receptors they activate and oestrogen signalling has been shown previously (Kalkhoven et al. 1994, Safe 1995). R1881 (androgen receptor/progesterone receptor agonist), dexamethasone (glucocorticoid receptor agonist) and Org 2058 (progesterone receptor agonist) did not have either agonistic or antagonistic effects on these cell lines (data not shown). All-trans retinoic acid (at-RA) was used to determine interference of retinoid signalling with the oestrogenic response and showed only a slight agonistic effect on $\mathrm{ER} \alpha$ with the highest concentration $\left(1 \times 10^{-6} \mathrm{M}\right.$ at-RA). No agonistic activity of at-RA on $\operatorname{ER} \beta$ or 

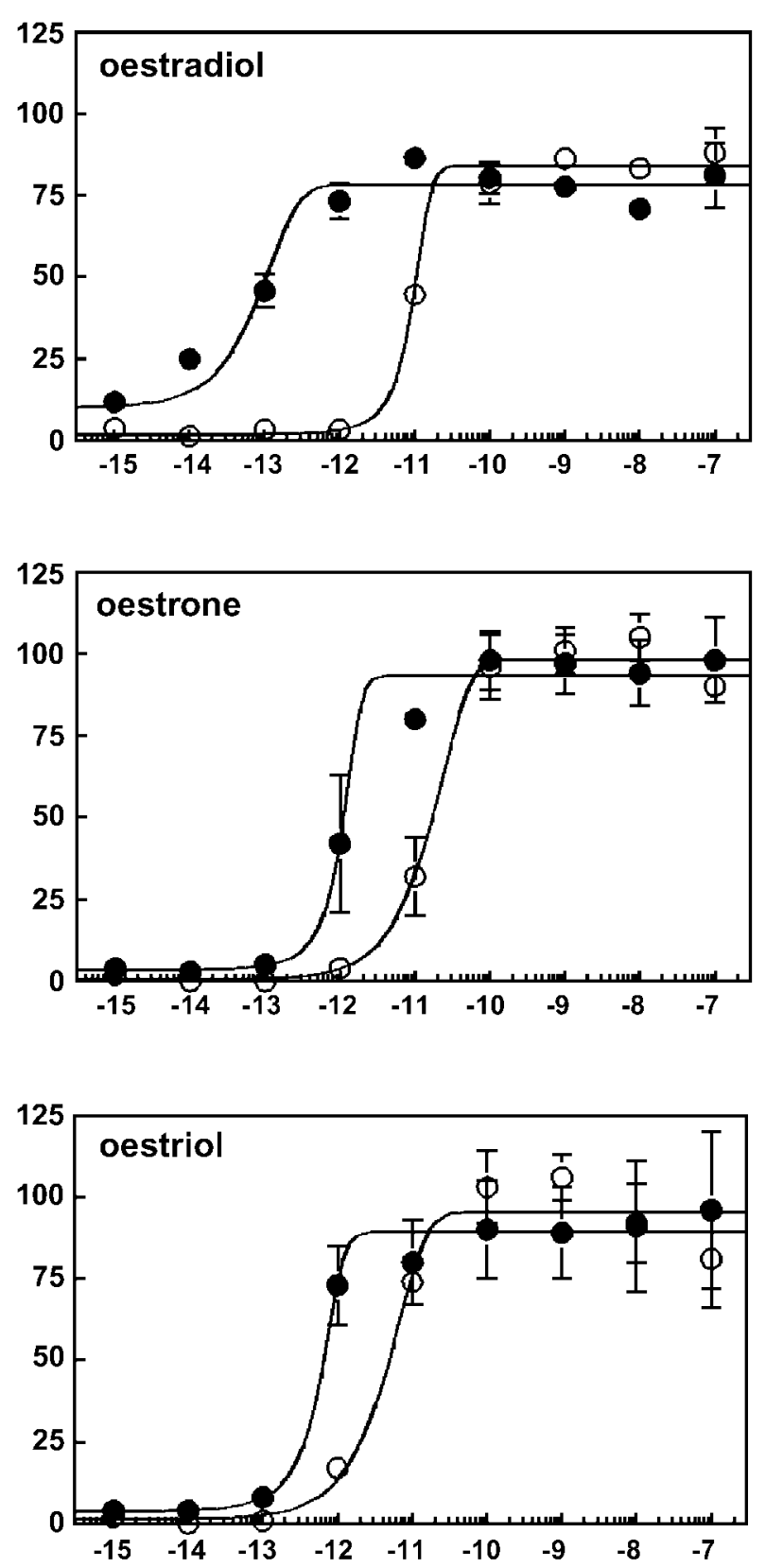

Figure 3 Transactivation of ER $\alpha$ and $E R \beta$ by oestrogens in stable oestrogen reporter cell lines. Data are presented as a percentage of maximal induction by $17 \beta$-oestradiol. Transactivation of the pERE-TATA-Luc reporter construct in the hER $\alpha$-containing cell line $(293 \mathrm{ER} \alpha)(-)$ and transactivation of the reporter construct in the hER $\beta$-containing cell line $(293 E R \beta)(\bigcirc)$. Abscissa: $\log M$ of hormone. Ordinate: transcriptional activity as percentage of maximal induction by $17 \beta$-oestradiol for each oestrogen receptor subtype. $n=7$ for $17 \beta$-oestradiol and $n=3$ for oestrone and oestriol; mean \pm S.E.M. is shown. antagonistic effects on either receptor could be detected. 2,3,7,8-Tetrachlorodibenzo-p-dioxin (TCDD), a ligand for the aryl-hydrocarbon receptor, did not show agonistic activity towards ER $\beta$, but did show a slight agonistic activity towards ER $\alpha$ at the highest concentration tested $\left(1 \times 10^{-8} \mathrm{M}\right)$. TCDD did not act as an antagonist in the 293ER $\alpha$ or $293 \mathrm{ER} \beta$ cell lines.

Several hormones from the MPF unit show oestrogenic activity, with $E R \beta$ selectivity

MPF hormones were tested both alone and in the presence of $17 \beta$-oestradiol to test for oestrogenic and antioestrogenic activity in the developed stable cell lines. Oestrone and oestriol showed strong activation of both ERs at low concentrations (Table 1 and Fig. 3). Strong activation was observed with the androgens dihydrotestosterone, testosterone, $3 \beta$-androstanediol and 5 -androsten-3 $\beta, 16 \alpha, 17 \beta$-triol, albeit at concentrations several orders of magnitude higher than the oestrogens (Table 1 and Fig. 4). Cholesterol, 16OH-androstenedione and progesterone showed no oestrogenic activity (Table 1 and Fig. 5). Very weak oestrogenic activity was observed for androstenedione and 17OH-pregnenolone. Strong transactivation of both oestrogen receptors was observed for DHEAS, pregnenolone, pregnenolone-S and $17 \mathrm{OH}-$ pregnenolone-S at high $\left(>1 \times 10^{-6} \mathrm{M}\right)$ concentrations (Table 1 and Fig. 5). DHEA and 16OH-DHEA showed strong activation of both oestrogen receptors at concentrations below $1 \times 10^{-6} \mathrm{M}$. None of the hormones present in the MPF unit showed any anti-oestrogenic activity when incubated with the EC50 concentration of $17 \beta$-oestradiol (data not shown). The preference of the hormones for activating either ER $\alpha$ or ER $\beta$ was evaluated by calculating the ratio of the EC25 of the hormone for ER $\beta$ divided by the EC25 of the hormone for ER $\alpha$. A number higher than 1 indicates a preference for activating $\mathrm{ER} \alpha$, while a number smaller than 1 indicates a preference for activating ER $\beta$. Surprisingly, most precursor hormones showed a similar preference for activating $\operatorname{ER} \beta$ and ER $\alpha$. This in contrast to $17 \beta$-oestradiol, oestrone and oestriol, which preferentially activated ER $\alpha$ (Table 1 ). Also the relative preference of the hormones for either ER $\alpha$ or ER $\beta$ was compared with the preference of the classic ligand $17 \beta$-oestradiol for these receptors (Table 1). $16 \mathrm{OH}-$ DHEA, pregnenolone and 17OH-pregnenolone had a more than 50 times higher relative preference for $\operatorname{ER} \beta$ than $17 \beta$-oestradiol. More than 100 times higher relative preference for ER $\beta$ was found for 5-androsten$3 \beta, 16 \alpha, 17 \beta$-triol, DHEA, pregnenolone-S, 17OHpregnenolone-S and testosterone when compared with $17 \beta$-oestradiol.

\section{Steroid extracts from mouse embryos show oestrogenic activity}

To determine the oestrogenic activity of the total pool of steroids present during gestation, steroids were extracted 

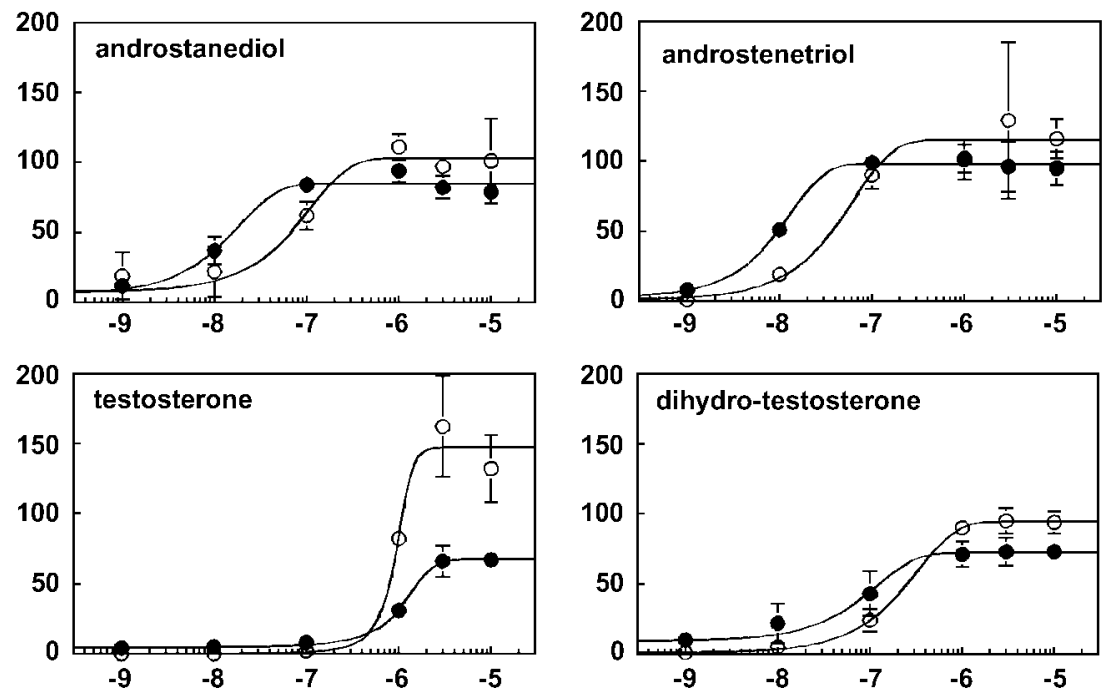

Figure 4 Transactivation of ER $\alpha$ and ER $\beta$ by androgens. Values shown are means (bars represent S.E.M.) of three independent experiments done in triplicate. Transactivation of the pERE-TATA-Luc reporter construct in the hER $\alpha$-containing cell line $(293 \mathrm{ER} \alpha)(\mathbf{0})$ and transactivation of the reporter construct in the hER $\beta$-containing cell line $(293 E R \beta)(\bigcirc)$. Abscissa: $\log M$ of hormone. Ordinate: transcriptional activity as percentage of maximal induction by $17 \beta$-oestradiol for each oestrogen receptor subtype.

from embryonic mice. The steroid and water fractions of mouse embryo extracts were tested for oestrogenic activity in the developed stable cell lines. Oestrogenic activity of the steroid fractions from the positive control samples (i.e. ovary and liver from adult female mice and embryos from DES-treated mice) was detected in both the 293ER $\alpha$ and 293ER $\beta$ cell lines. This indicated that steroids were extracted and the cell lines were responding to them. When testing the steroid fractions extracted from the embryos in the 293ER $\beta$ cell line, oestrogenic activity was too low for calculating EEQ values. However, oestrogenic activity of the same steroid fractions was detected in the 293ER $\alpha$ cell line and EEQ values could be calculated. The steroid fractions of $12.5 \mathrm{dpc}$ males had an EEQ value of $3.9 \times 10^{-14} \mathrm{M}(\mathrm{CV}=7 \%)$, whereas the steroid fractions of females of the same age had an EEQ of $3.0 \times 10^{-14} \mathrm{M}$ $(\mathrm{CV}=17 \%)$ per g tissue (Fig. 6). Extracts from males and females aged 14.5 and $16.5 \mathrm{dpc}$ had $\mathrm{EEQ} / \mathrm{g}$ values $0 \cdot 9-1 \times 10^{-14} \mathrm{M}(\mathrm{CV}=15-24 \%)$. There was no significant difference in the averages of the EEQ values of the steroid extracts between any of the ages or sexes, determined with a two-paired Student's $t$-test. When a subset of fractions (including the positive control samples) was co-incubated with the anti-oestrogen ICI 182780 $\left(1 \times 10^{-7} \mathrm{M}\right)$, no oestrogenic activity could be detected. This indicated that the activation of the reporter construct in the stable cell lines was mediated by the oestrogen receptor (Fig. 7). Adding 17 $\beta$-oestradiol to the combination of extracts and ICI 182780 showed activation of the reporter construct, indicating that the combination of steroid extract and ICI 182780 was not toxic for the cells. The water fractions of embryo extracts, possibly containing sulphated steroids, were subsequently desulphated, extracted and tested again for oestrogenic activity. None of the desulphated fractions showed any oestrogenic activity in either of the cell lines. The positive control, $17 \beta$-oestradiol glucuronide, was deconjugated during the incubations (data not shown) indicating that the deconjugation reactions were effective.

\section{Discussion}

We found that precursor steroids such as DHEA (-S), 16OH-DHEA, pregnenolone (-S), 17OH-pregnenolone $(-S)$ and androgens like $3 \beta$-androstanediol, 5-androsten$3 \beta, 16 \alpha, 17 \beta$-triol, dihydrotestosterone and testosterone all stimulated transcriptional activity via both $\mathrm{ER} \alpha$ and $\mathrm{ER} \beta$. Surprisingly, these ligands were more potent ER $\beta$ activators when compared with the most prominent oestrogen receptor ligand $17 \beta$-oestradiol, which preferentially activates ER $\alpha$. The activation of ER $\beta$ by DHEA, pregnenolone and their hydroxylated and sulphated forms is of considerable interest and suggests that these hormones, which circulate at much higher levels than $17 \beta$-oestradiol, could be natural ER $\beta$ ligands rather than $17 \beta$-oestradiol. DHEA stimulated both oestrogen receptors at $1 \times$ $10^{-8} \mathrm{M}$. It is unlikely that this is due to conversion of DHEA to $17 \beta$-oestradiol via either androstenediol or androstenedione, because $3 \beta-\mathrm{HSD}$ and $17 \beta-\mathrm{HSD}$ are 

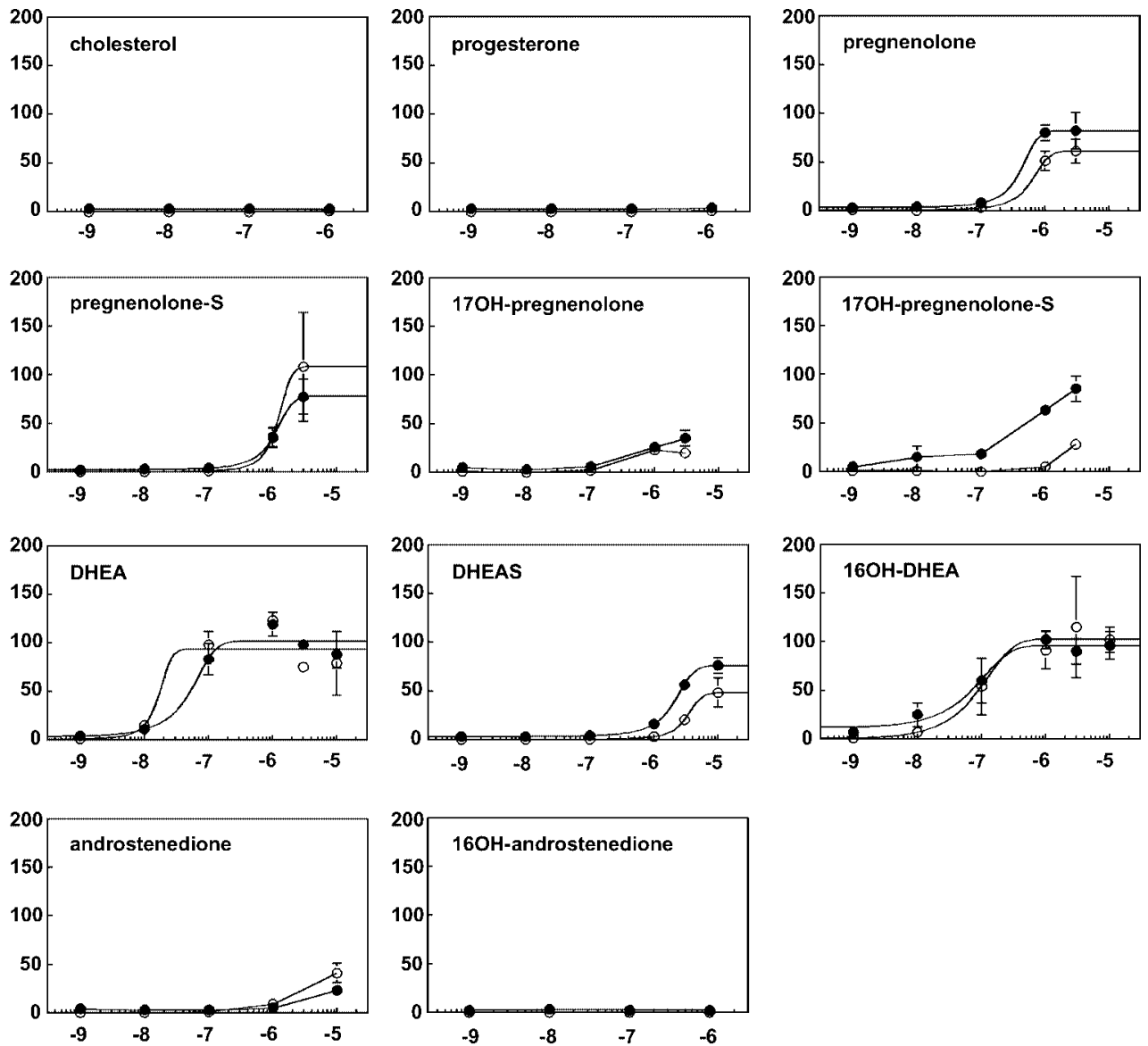

Figure 5 Transactivation of ER $\alpha$ and ER $\beta$ by hormones from the MPF unit. Values shown are means (bars represent S.E.M.) of three independent experiments done in triplicate (for $17 \mathrm{OH}$-pregnenolone, two independent experiments). Transactivation of the pERE-TATA-Luc reporter construct in the hER $\alpha$-containing cell line $(293 E R \alpha)(-)$ and transactivation of the reporter construct in the hER $\beta$-containing cell line (293ER $\beta)$ (○). Abscissa: $\log M$ of hormone. Ordinate: transcriptional activity as percentage of maximal induction by $17 \beta$-oestradiol for each oestrogen receptor subtype.

absent from the 293 HEK cells (Suzuki et al. 2000). DHEA has been shown to bind both ER $\alpha$ and $\operatorname{ER} \beta$, albeit at concentrations more than 1000 times higher than $17 \beta$-oestradiol (Kuiper et al. 1997). DHEA also activates ER $\alpha$-mediated transcription in yeast (Nephew et al. 1998). In the present study, the 16-hydroxylated form of DHEA was able to transactivate both ER $\alpha$ and ER $\beta$, albeit at slightly higher concentrations than DHEA itself. The sulphated form of DHEA was less oestrogenic than DHEA and showed agonistic activity at a concentration of $1 \times 10^{-6} \mathrm{M}$, which supports the hypothesis that sulphation reduces the biologic activity of hormones. The data showed that the concentrations at which DHEA, $16 \mathrm{OH}-$ DHEA and DHEAS are found in human umbilical cord blood at term $\left(1.3 \times 10^{-6} \mathrm{M}, 3.6 \times 10^{-6} \mathrm{M}\right.$ and $5 \times 10^{-6} \mathrm{M}$ respectively; Guez et al. 1976, Parker et al. 1982, Simmons et al. 1994) are sufficient to activate oestrogen receptors. This may suggest that these three hormones contribute to the total oestrogen exposure of the human foetus.

Pregnenolone and $17 \mathrm{OH}$-pregnenolone and their respective sulphated forms showed oestrogenic activity in both cell lines at micromolar concentrations, with pregnenolone being the most potent ligand. Pregnenolone concentrations, however, only reach about $6 \times 10^{-8} \mathrm{M}$ in cord blood at term (Mathur et al. 1980) and it remains to be evaluated whether concentrations in target tissues will reach levels sufficient to activate oestrogen receptors. However, the sulphated form of pregnenolone reaches concentrations of up to $2.5 \times 10^{-5} \mathrm{M}$ in human foetal serum at term (de Peretti \& Mappus 1983), which in the present study was sufficient to activate both ER $\alpha$ and ER $\beta$. Surprisingly, the sulphated form of 17-hydroxylated pregnenolone was more potent in inducing an oestrogenic response via ER $\alpha$ than the un-sulphated form. We cannot exclude the possibility that pregnenolone and its sulphated 


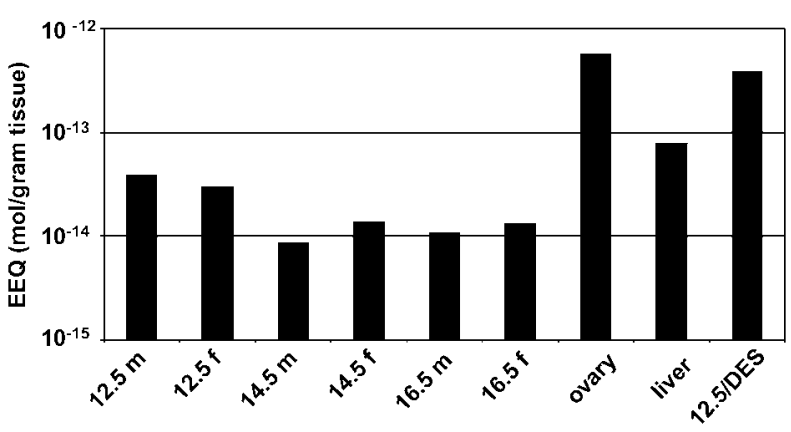

Figure 6 Oestrogenic activity of embryo extracts; oestradiol equivalents (EEQ) ( $\mathrm{mol} / \mathrm{g}$ ) following 24-h incubation in the 293ER $\alpha$ cell line of steroid fractions from extracted mouse embryos and positive control samples (ovary and liver from adult female mice; mouse embryos isolated on 12.5 days post coitum (dpc) $24 \mathrm{~h}$ after in utero DES treatment). m: male; f: female. Ages shown are dpc. Results are average, the CV values are for 12.5 days post coitum (dpc) male $7 \%(n=10)$ and female $17 \%(n=5)$, for 14.5 dpc male $15 \%(n=9)$ and female $24 \%(n=7)$ and for $16.5 \mathrm{dpc}$ male $17 \%(n=6)$ and female $21 \%(n=8)$. For the positive control samples, $n=3$ for adult tissues and $n=2$ for DES-exposed embryos.

and hydroxylated forms are metabolised to DHEA in 293 HEK cells by CYP17. However, the fact that $17 \mathrm{OH}-$ pregnenolone, which is only one conversion step from DHEA, is less active than pregnenolone (two steps from DHEA) argues against conversion of these precursors in 293 HEK cells.

Three androgens, 3 $\beta$-androstenediol, androstenetriol and dihydrotestosterone, showed transactivation of both oestrogen receptors at concentrations around $10^{-8} \mathrm{M}$. As the only androgen, testosterone showed transactivation at concentrations exceeding $10^{-6} \mathrm{M}$. Of these androgens, only the concentration of testosterone in the mouse foetus

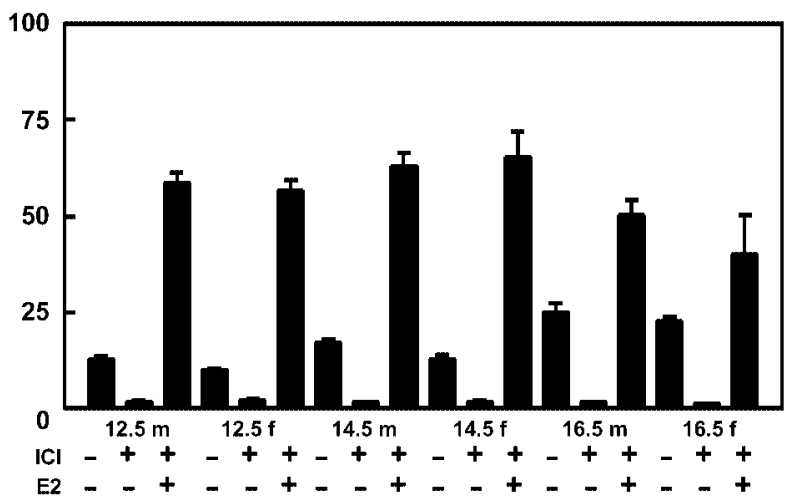

Figure 7 Luciferase induction of steroid extracts is mediated by ER $\alpha$. Luciferase induction after 24-h incubation of the steroid fractions (pooled for each age and sex) alone and in combination with the anti-oestrogen $\mathrm{ICl} 182780\left(\mathrm{ICl} ; 10^{-8} \mathrm{M}\right)$ or in combination with $\mathrm{ICl}$ and $17 \beta$-oestradiol $\left(\mathrm{E} 2 ; 10^{-9} \mathrm{M}\right)$ in the 293ER $\alpha$ cell line. m: male; f: female. Ages shown are dpc. Ordinate: transcriptional activity as percentage of maximal induction by $17 \beta$-oestradiol for each oestrogen receptor subtype. is known: $1.6 \times 10^{-8} \mathrm{M}$ in males and $0.7 \times 10^{-8} \mathrm{M}$ in females (vom Saal et al. 1990). The total concentration of testosterone in human cord blood is $1-2 \times 10^{-8} \mathrm{M}$ (Mathur et al. 1980, Simmons et al. 1994) in both males and females. From our results, these levels seem insufficient to induce oestrogen receptor transactivation.

Interestingly, in this study, the hormones DHEA, 5 -androsten-3 $\beta, 16 \alpha, 17 \beta$-triol, testosterone and $(17 \mathrm{OH})$ pregnenolone-S have a similar preference for activating ER $\beta$ and ER $\alpha$. This in contrast to $17 \beta$-oestradiol, which preferentially activates ER $\alpha$. It has been shown that some synthetic oestrogens and naturally existing ligands such as phyto-oestrogens have different relative affinities for ER $\alpha$ versus ER $\beta$ when compared with $17 \beta$-oestradiol, although most ligands bind both oestrogen receptor subtypes with comparable affinity (Kuiper et al. 1998). DHEA and dihydrotestosterone have previously been shown to bind two to three times stronger to $\mathrm{ER} \beta$ than to $\operatorname{ER} \alpha$ (Kuiper et al. 1997), which partially explains the observed preferential activation of ER $\beta$ by these hormones when compared with $17 \beta$-oestradiol. DHEA, pregnenolone and their sulphates have been indicated to be involved in neural processes such as memory in the adult (Baulieu 1997). The receptors involved in the direct action of DHEA $(-S)$ and pregnenolone $(-S)$ in the brain are, however, unknown (Baulieu \& Robel 1998). The activation of $E R \alpha$ and $E R \beta$ by these hormones could indicate that these processes are mediated by oestrogen receptors. In particular, ER $\beta$, which is prominently expressed in several important brain regions, is a likely candidate. The relatively higher affinity of DHEA for $\operatorname{ER} \beta$ is also interesting in the light of co-expression of sulphatases (Compagnone et al. 1997) and ER $\beta$ at ossification sites in the mouse embryo (Lemmen et al. 1999). Local conversion of DHEAS to DHEA could therefore activate ER $\beta$ in these ossification centres. Recently, it was found that ER $\beta$ is highly expressed in human foetal tissues at 13 and 20 weeks of gestation (Takeyama et al. 2001). In particular, the adrenal gland, where DHEAS is produced, was found to be a major site of $E R \beta$ expression in humans. ER $\alpha$ was barely detectable during this period, suggesting that ER $\beta$ would be the main effector of oestrogen signalling in humans at this period of gestation.

Given the ability of MPF steroids to activate oestrogen receptors, we were interested in the oestrogenic activity of hormones present in the foetus. In steroid extracts from mouse embryos of different ages, the highest activity, although not significant, was found at $12.5 \mathrm{dpc}$. If the measured oestrogenic activity derived from $17 \beta$-oestradiol or testosterone and their precursors, the peak of oestrogenic activity at $12.5 \mathrm{dpc}$ seems to contradict the peak at $17.5 \mathrm{dpc}$ of either $17 \beta$-oestradiol in the maternal serum (Barkley et al. 1977) or testosterone in foetuses (Weisz \& Ward 1980). However, data from the foetal rabbit showed that, although $17 \beta$-oestradiol production increases during pregnancy, a drop is observed when the $17 \beta$-oestradiol 
concentrations are plotted per mg gonadal protein (George $\&$ Wilson 1978). This suggests that the increase in gonadal growth counteracts the effect of a rise in $17 \beta$-oestradiol production and consequently the net amount of $17 \beta$-oestradiol per $\mathrm{mg}$ protein drops. A similar effect could occur when the EEQs are corrected for total body weight, as was done in the present experiments. The activation profile of the extracts, capable only of activating the 293ER $\alpha$ cell line and not the 293ER $\beta$ cell line, suggested activation by a hormone that preferentially activates ER $\alpha$. Based on the activation profiles identified, this would suggest that the main contribution to the total pool of oestrogenic activity is not by precursors like DHEA but rather by classical oestrogens. Since aromatase activity is present in mammalian foetal gonads of both sexes (Weniger 1990) as well as in the human foetal liver (Schindler 1975), both male and female foetuses are capable of producing oestrogens from precursors. It should be noted that the cell lines used in the present study contained human oestrogen receptors and a slight difference of the extracts to activate murine oestrogen receptors cannot be ruled out. However, studies by Matthews et al. (2000) showed that human and mouse ER $\alpha$ react in a very similar manner to steroidal and anti-oestrogenic compounds. We therefore expect that differences between activation of human versus murine oestrogen receptors by the steroid hormones tested will be quantitative rather than qualitative.

In conclusion, DHEA, DHEAS and pregnenolone-S were able to activate $\operatorname{ER} \alpha$ and $\operatorname{ER} \beta$ at physiological concentrations. Interestingly, precursor steroids and androgens showed a relative preference for $\operatorname{ER} \beta$ transactivation over ER $\alpha$ transactivation when compared with transactivation by $17 \beta$-oestradiol and other oestrogens. Extracts from mouse embryos contained detectable oestrogenic activity, suggesting that endogenous steroids present in the murine embryo are capable of activating oestrogen receptors. The oestrogen precursors examined could contribute to the total pool of endogenous oestrogens during foetal life. These precursors could also be involved in the hypothesised link between exposure to high endogenous oestrogens and breast and prostate cancer or cryptorchidism.

\section{Acknowledgement}

This work was supported by European Community grant PL951223 (BVDB).

\section{References}

Banerji J, Rusconi S \& Schaffner W 1981 Expression of a beta-globin gene is enhanced by remote SV40 DNA sequences. Cell 27 299-308.
Barkley MS, Michael SD, Geschwind II \& Bradford GE 1977 Plasma testosterone during pregnancy in the mouse. Endocrinology 100 1472-1475.

Baulieu EE 1997 Neurosteroids: of the nervous system, by the nervous system, for the nervous system. Recent Progress in Hormone Research 52 1-32.

Baulieu EE \& Robel P 1998 Dehydroepiandrosterone (DHEA) and dehydroepiandrosterone sulfate (DHEAS) as neuroactive neurosteroids. PNAS 95 4089-4091.

Carr BR 1996 Fertilization, implantation, and endocrinology of pregnancy. In Textbook of Endocrine Physiology, pp 223-243. Eds JE Griffin \& SR Ojeda. New York: Oxford University Press.

Chomczynski P \& Sacchi N 1987 Single-step method of RNA isolation by acid guanidinium thiocyanate-phenol-chloroform extraction. Analytical Biochemistry 162 156-159.

Compagnone NA, Salido E, Shapiro LJ \& Mellon SH 1997 Expression of steroid sulfatase during embryogenesis. Endocrinology 138 4768-4773.

Couse JF, Hewitt SC, Bunch DO, Sar M, Walker VR, Davis BJ \& Korach KS 1999 Postnatal sex reversal of the ovaries in mice lacking estrogen receptors alpha and beta. Science 286 2328-2331.

Den K, Haruyama T, Hagiwara H, Fujii KT, Kambegawa A, Takami T, Yoshida T \& Takagi S 1979 Plasma levels of 16 alpha-hydroxypregnenolone, 16 alpha-hydroxyprogesterone and 16 alpha-hydroxydehydroepiandrosterone in the fetus and neonates. Endocrinologia Japonica 26 439-447.

Dupont S, Krust A, Gansmuller A, Dierich A, Chambon P \& Mark M 2000 Effect of single and compound knockouts of estrogen receptors alpha (ERalpha) and beta (ERbeta) on mouse reproductive phenotypes. Development 127 4277-4291.

George FW \& Wilson JD 1978 Oestrogen content of the embryonic rabbit ovary. Nature 274 172-173.

Gore-Langton RE \& Armstrong DT 1994 Follicular steroidogenesis and its control. In The Physiology of Reproduction, pp 571-627. Eds E Knobil \& JD Neill. New York: Raven Press Ltd.

Green S, Walter P, Kumar V, Krust A, Bornert JM, Argos P \& Chambon P 1986 Human oestrogen receptor cDNA: sequence, expression and homology to v-erb-A. Nature 320 134-139.

Guez G, Gandar R, Schuy E, Knapstein P \& Oertel G 1976 Free and sulfoconjugated dehydroepiandrosterone, cyclic adenosine- $3^{\prime}, 5^{\prime}-$ monophosphate, and free estriol in maternal and cord blood. Experientia 32 117-118.

Herbst AL, Ulfelder H \& Poskanzer DC 1971 Adenocarcinoma of the vagina. Association of maternal stilbestrol therapy with tumor appearance in young women. New England Journal of Medicine 284 878-881.

Kalkhoven E, Kwakkenbos-Isbrucker L, de Laat SW, van der Saag PT \& van der Burg B 1994 Synthetic progestins induce proliferation of breast tumor cell lines via the progesterone or estrogen receptor. Molecular and Cellular Endocrinology 102 45-52.

Krege JH, Hodgin JB, Couse JF, Enmark E, Warner M, Mahler JF, Sar M, Korach KS, Gustafsson JÅ \& Smithies O 1998 Generation and reproductive phenotypes of mice lacking estrogen receptor beta. PNAS 95 15677-15682.

Kuiper GG, Enmark E, Pelto-Huikko M, Nilsson S \& Gustafsson JÅ 1996 Cloning of a novel receptor expressed in rat prostate and ovary. PNAS 93 5925-5930.

Kuiper GG, Carlsson B, Grandien K, Enmark E, Haggblad J, Nilsson S \& Gustafsson JA 1997 Comparison of the ligand binding specificity and transcript tissue distribution of estrogen receptors alpha and beta. Endocrinology 138 863-870.

Kuiper GG, Lemmen JG, Carlsson B, Corton JC, Safe SH, van der Saag PT, van der Burg B \& Gustafsson JÅ 1998 Interaction of estrogenic chemicals and phytoestrogens with estrogen receptor beta. Endocrinology 139 4252-4263.

Legler J, van den Brink CE, Brouwer A, Murk AJ, van der Saag PT, Vethaak AD \& van der Burg B 1999 Development of a stably 
transfected estrogen receptor-mediated luciferase reporter gene assay in the human T47D breast cancer cell line. Toxicological Sciences 48 55-66.

Legler J, Jonas A, Lahr J, Vethaak AD, Brouwer A \& Murk AJ 2002 Biological measurement of estrogenic activity in urine and bile conjugates with the in vitro ER-CALUX reporter gene assay. Environmental and Toxicological Chemistry 21 473-479.

Lemmen JG, Broekhof JL, Kuiper GG, Gustafsson JÅ, van der Saag PT \& van der Burg B 1999 Expression of estrogen receptor alpha and beta during mouse embryogenesis. Mechanisms of Development 81 163-167.

Lubahn DB, Moyer JS, Golding TS, Couse JF, Korach KS \& Smithies O 1993 Alteration of reproductive function but not prenatal sexual development after insertional disruption of the mouse estrogen receptor gene. PNAS 90 11162-11166.

McLachlan JA, Newbold RR \& Bullock B 1975 Reproductive tract lesions in male mice exposed prenatally to diethylstilbestrol. Science 190 991-992.

Mathur RS, Landgrebe S, Moody LO, Powell S \& Williamson HO 1980 Plasma steroid concentrations in maternal and umbilical circulation after spontaneous onset of labor. Journal of Clinical Endocrinology and Metabolism 51 1235-1238.

Matthews J, Celius T, Halgren R \& Zacharewski T 2000 Differential estrogen receptor binding of estrogenic substances: a species comparison. Journal of Steroid Biochemistry and Molecular Biology 74 223-234

Maume D, Deceuninck Y, Pouponneau K, Paris A, Le Bizec B \& Andre F 2001 Assessment of estradiol and its metabolites in meat. Acta Pathologica, Microbiologica, et Immunologica Scandinavica 103 S365-S371.

Miller WR \& Sharpe RM 1998 Environmental oestrogens and human reproductive cancers. Endocrine-Related Cancer 5 69-96.

Mosselman S, Polman J \& Dijkema R 1996 ER beta: identification and characterization of a novel human estrogen receptor. FEBS Letters 392 49-53.

Nephew KP, Sheeler CQ, Dudley MD, Gordon S, Nayfield SG \& Khan SA 1998 Studies of dehydroepiandrosterone (DHEA) with the human estrogen receptor in yeast. Molecular and Cellular Endocrinology 143 133-142.

Nuclear receptors nomenclature committee 1999 A unified nomenclature system for the nuclear receptor superfamily. Cell $\mathbf{9 7}$ 161-163.

Numazawa M, Osada R, Tsuji M \& Osawa Y 1985 Highperformance liquid chromatographic determination of aromatization of 16 alpha-hydroxylated androgens with human placental microsomes. Analytical Biochemistry 146 75-81.

Ojeda SR 1996 Female reproductive function. In Textbook of Endocrine Physiology, pp 164-200. Eds JE Griffin \& SR Ojeda. New York, USA: Oxford University Press.

Parker CR, Leveno K, Carr BR, Hauth J \& MacDonald PC 1982 Umbilical cord plasma levels of dehydroepiandrosterone sulfate during human gestation. Journal of Clinical Endocrinology and Metabolism 54 1216-1220.

Pasqualini JR \& Kincl F 1985 Hormones and the fetus. Oxford, UK: Pergamon Press Ltd.

de Peretti E \& Mappus E 1983 Pattern of plasma pregnenolone sulfate levels in humans from birth to adulthood. Journal of Clinical Endocrinology and Metabolism 57 550-556.

Quaedackers ME, van den Brink CE, Wissink S, Schreurs RH, Gustafsson JÅ, van der Saag PT \& van der Burg B 2001 4-Hydroxytamoxifen trans-represses nuclear factor-kappaB activity in human osteoblastic U2-OS cells through estrogen receptor (ER)alpha, and not through ERbeta. Endocrinology 142 1156-1166. te Riele H, Maandag ER, Clarke A, Hooper M \& Berns A 1990 Consecutive inactivation of both alleles of the pim-1 protooncogene by homologous recombination in embryonic stem cells. Nature 348 649-651.

vom Saal F, Quadagno DM, Even MD, Keisler LW, Keisler DH \& Khan S 1990 Paradoxical effects of maternal stress on fetal steroids and postnatal reproductive traits in female mice from different intrauterine positions. Biology of Reproduction 43 751-761.

Safe SH 1995 Modulation of gene expression and endocrine response pathways by 2,3,7,8-tetrachlorodibenzo-p-dioxin and related compounds. Pharmacology and Therapeutics 67 247-281.

Schindler AE 1975 Steroid metabolism of fetal tissues. II. Conversion of androstenedione to estrone. American Journal of Obstetrics and Gynecology 123 265-268.

Sharpe RM \& Skakkebaek NE 1993 Are oestrogens involved in falling sperm counts and disorders of the male reproductive tract? Lancet 341 1392-1395.

Shibata A \& Minn AY 2000 Perinatal sex hormones and risk of breast and prostate cancers in adulthood. Epidemiological Reviews 22 239-248.

Simmons D, France JT, Keelan JA, Song L \& Knox BS 1994 Sex differences in umbilical cord serum levels of inhibin, testosterone, oestradiol, dehydroepiandrosterone sulphate, and sex hormonebinding globulin in human term neonates. Biology of the Neonate $65287-294$.

Solomon S 1994 The primate placenta as an endocrine organ: steroids. In The Physiology of Reproduction, pp 863-873. Eds E Knobil \& JD Neill. New York: Raven Press Ltd.

Sonneveld E, van den Brink CE, van der Leede BM, Schulkes RK, Petkovich M, van der Burg B \& van der Saag PT 1998 Human retinoic acid (RA) 4-hydroxylase (CYP26) is highly specific for all-trans-RA and can be induced through RA receptors in human breast and colon carcinoma cells. Cell Growth and Differentiation 9 629-637.

Suzuki T, Sasano H, Andersson S \& Mason JI 20003 Betahydroxysteroid dehydrogenase/delta5->4-isomerase activity associated with the human 17 beta-hydroxysteroid dehydrogenase type 2 isoform. Journal of Clinical Endocrinology and Metabolism $\mathbf{8 5}$ 3669-3672.

Takeyama J, Suzuki T, Inoue S, Kaneko C, Nagura H, Harada N \& Sasano H 2001 Expression and cellular localization of estrogen receptors alpha and beta in the human fetus. Journal of Clinical Endocrinology and Metabolism 86 2258-2262.

Toppari J \& Skakkebaek NE 1998 Sexual differentiation and environmental endocrine disrupters. Baillieres Clinical Endocrinology and Metabolism 12 143-156.

Voutilainen R \& Miller WL 1986 Developmental expression of genes for the stereoidogenic enzymes P450 scc (20,22-desmolase), P450c17 (17 alpha-hydroxylase/17,20-lyase), and P450c21 (21-hydroxylase) in the human fetus. Journal of Clinical Endocrinology and Metabolism 63 1145-1150.

Weisz J \& Ward IL 1980 Plasma testosterone and progesterone titers of pregnant rats, their male and female fetuses, and neonatal offspring. Endocrinology 106 306-316.

Weniger JP 1990 Aromatase activity in fetal gonads of mammals. Journal of Developmental Physiology 14 303-306.

Received 10 May 2002

Accepted 14 May 2002 